\title{
PENGARUH PENGELUARAN per MAHASISWA, MOTIVASI BELAJAR DAN TINGKAT KECERDASAN SPIRITUAL TERHADAP PRESTASI AKADEMIK
}

\author{
Romauli Nainggolan \\ IBM lecturer at Ciputra University \\ roma_ps@yahoo.com
}

\begin{abstract}
ABSTRAK
Penelitian ini bertujuan untuk mengetahui pengaruh antara pengeluaran per mahasiswa, motivasi belajar dan tingkat kecerdasan spiritual terhadap indeks prestasi mahasiswa Manajemen Universitas CIputra. Hal ini disebabkan fenomena yang terjadi yaitu rendahnya indeks prestasi mahasiswa justru terjadi dikalangan mahasiswa yang mempunyai biaya pengeluaran hidup yang lebih tinggi. Karena fenomena ditemukan mahasiswa status ekonomi tinggi mempunyai peningkatan IPK dibawah mahasiswa status ekonomi lemah, maka peneliti bertujuan untuk mengamati pengaruh pengeluaran tiap mahasiswa, tingkat motivasi dan tingkat kecerdasan spiritual mahasiswa terhadap indeks prestasi mahasiswa. Penelitian ini dilakukan pada bulan Oktober - Februari 2017 dan jumlah populasi mahasiswa manjemen sebanyak 1.308 mahasiswa. Model Analisis pada penelitian ini adalah model Regresi logistik. Sample sebanyak 86 responden dengan metode pengambilan purposive sampling dengan instrument angket dan pengolahan data dengan program SPPS. Dari analisis deskriptif dan statistic diperoleh hasil bahwa indeks prestasi mahasiswa Manajemen UC berada pada kategori menurun dan sangat menurun bukan dipengaruhi oleh pengeluaran per mahasiswa, tingkat motivasi belajar dan kecerdasan spiritual. Karena ke -3 variabel ini hanya 3, 6\% memberi efek kepada indeks prestasi belajar, sisanya dipengaruhi oleh factor lain. Implikasinya adalah para dosen dan orangtua mahasiswa harus tetap memberikan dukungan materi, motivasi dan dukungan spiritual kepada mahasiswa untuk menhindari indeks prestasi yang menurun.
\end{abstract}

Kata Kunci: Pengeluaran mahasiswa, motivasi belajar, kecerdasan spiritual, indeks prestasi.

\section{PENDAHULUAN}

Sekolah bisnis (school of entrepreneurship) menjadi jurusan yang diminati oleh orang muda saat ini. Kebanyakan Universitas dan sekolah tinggi memiliki jurusan manajemen dengan tawaran pembelajaran berbasis bisnis. Menurut data BAN PT bahwa Universitas terbaik di Indonesia jurusan Manajemen FE (Fakultas Ekonomi) adalah universitas yang memiliki jurusan manajemen terakreditas A di Ban-PT. Pada tahun 2016 Jurusan International Business Manajemen (IBM) Universitas Ciputra mendapatkan akreditasi A dari Ban - PT. Sehingga akreditasi ini mendongkrak popularitas IBM dan mendorong peminat di jurusan ini semakin tinggi. Pada tahun ajaran baru 2014/2015 terdaftar 388 mahasiswa dan pada tahun 2015/2016 terdaftar 384 mahasiswa baru. Sehingga saat ini jumlah mahasiswa IBM yang aktif mencapai 1.308 orang.

Kebanyakan mahasiwa yang kuliah di jurusan manajemen UC berasal dari luar kota Surabaya dan luar pulau Jawa sehingga menyebabkan pengeluaran biaya hidup semakin tinggi karena biaya tempat tinggal (kost) dan jauh dari orang tua. Pengeluaran mahasiswa terdiri dari konsumsi makanan dan non makanan merupakan rata rata pengeluaran mahasiswa yang sedang study (Clinton, 2015). Dalam sebuah penelitian yang dilakukan terhadap seluruh mahasiswa jurusan MIPA Universitas IPB bahwa pengeluaran mahasiswa untuk konsumsi makanan lebih besar dibandingkan konsumsi non makanan. Besarnya jumlah uang saku pada masing-masing mahasiswa tidak sama, mahasiswa yang menerima uang saku dalam jumlah yang lebih besar akan mempunyai kecenderungan melakukan konsumsi lebih besar dibandingkan dengan mahasiswa yang menerima uang saku lebih sedikit. Karena konsumsi adalah biaya pengeluaran untuk pembelian barang-barang dan jasa guna mendapatkan kepuasan ataupun memenuhi kebutuhannya (Samuelson dan William, 2001).

Kebanyakan pengeluaran per mahasiswa yang tinggi dilatarbelakangi dari keluarga ekonomi tinggi. Sedangkan pengeluaran per mahasiswa yang rendah dilatar belakang dari keluarga 
ekonomi rendah. Permasalahan yang banyak terjadi adalah kecenderungan mahasiswa dengan pengeluaran yang tinggi mengalami peningkatan indeks prestasi yang lebih rendah dibandingkan mahasiswa dengan pengeluaran rendah. Oleh karena itu penelitian ini akan mengamati pengaruh pengeluaran terhadap indeks prestasi mahasiswa. Selain mengamati pengaruh pengeluaran mahasiswa terhadap indeks prestasi mahasiswa, peneliti menambahkan variabel motivasi belajar dan kecerdasan intelektual. Dorongan motivasi belajar pasti dimiliki oleh semua mahasiswa dari berbagai golongan status ekonomi, karena semua mahasiswa memiliki keinginan untuk sukses di dalam study dan bisnis. Variabel terakhir adalah kecerdasan intelektual mahasiswa, penting untuk ditinjau karena berkaitan dengan kemampuan mahasiswa bertahan hidup di lingkungan kampus dan jauh dari orangtua.

\section{Rumusan Masalah}

Berdasarkan latar belakang yang dihadapi mahasiswa dan jurusan manajemen, maka penelitian ini akan menjawab permasalahan yaitu

1. Bagaimana pengaruh pengeluaran per mahasiswa terhadap prestasi akademik.

2. Bagaimana pengaruh motivasi belajar mahasiswa terhadap prestasi akademik.

3. Bagaimana pengaruh tingkat spiritual mahasiswa terhadap prestasi akademik.

\section{Tujuan Penelitian}

Hasil penelitian ini bertujuan untuk

1. Mengetahui pengaruh pengeluaran per mahasiswa terhadap prestasi akademik.

2. Mengetahui pengaruh motivasi belajar mahasiswa terhadap prestasi akademik.

3. Mengetahui pengaruh tingkat spiritual mahasiswa terhadap prestasi akademik.

\section{KAJIAN PUSTAKA}

Penelitian terdahulu

Tahun 2014 dalam sebuah data base pusat publikasi Universitas Vermont berjudul "Spending and Student Achievement: Money Matters When Equity is at Issue" menjelaskan hubungan antara biaya pengeluaran siswa dan prestasi akademik siswa di Amerika. Penelitian pada kelas 4, kelas 8 dan kelas 10 dengan membandingkan sekolah yang lebih tinggi tingkat investasi pendidikannya dibandingkan dengan sekolah yang lebih rendah tingkat investasi pendidikannya. Ditemukan bahwa sekolah yang investasi pendidikannya lebih tinggi mempengaruhi prestasi akademik siswa. Hanya sedikit dampak atau pengaruh terhadap prestasi akademik siswa untuk tingkat investasi menengah investasi (James, 2014). Investasi yang tidak sama atau berbeda-beda di sekolah sekolah setiap tahun tidak menunjukkan perubahan penting dan besar, namun hasilnya berdampak kepada hasil belajar siswa dan prestasi akademik siswa.

Tahun 2012 dalam sebuah jurnal internasional berjudul "The Relationship Between per Pupil Expenditure and Student Achievement in Tennessee". Penelitian ini menguji hubungan antara prestasi akademik siswa SMA, pengeluaran per orang, pendaftaran distrik sekolah, latar belakang demografis siswa (suku, tingkat ekonomi dan agama) dan letak demografis sekolah (Timur, Tengah dan Barat) di daerah Tennessee. Ada 136 sistem sekolah di negara bagian Tennessee, hanya 119 sekolah yang system penilaian yang tetap beroperasi. Temuan menunjukkan bahwa rata-rata skor ACT di Tennessee pada tahun 2008 adalah 20,7dan penilaian menulis rata-rata adalah 4,1 . Rata-rata pengeluaran per murid adalah $\$ 8.345$. Penelitian ini mengungkapkan bahwa pengeluaran per siswa tidak memiliki hubungan yang signifikan dengan skor penilaian penulisan ACT dan TCAP. Implikasi adalah pemberian uang untuk biaya 
keperluan sekolah tidak akan mempengaruhi peningkatan prestasi siswa. Tapi bagaimanapun uang tetap harus dikeluarkan untuk tetap dapat study (William \& Larry, 2012).

Tahun 2010 dalam sebuah penelitian ilmiah berjudul "Hubungan antara kecerdasan spiritual Dengan motivasi belajar pada mahasiswa Fakultas Kedokteran Universitas Sebelas Maret". Penelitian ini menggunakan jenis penelitian observasional analitik dengan desain penelitian korelasional dan pendekatan cross sectional. Jumlah sampel 115 responden mahasiswa kedokteran. Hasil penelitian dari analisis korelasi product moment didapatkan hasil $\mathrm{r}$ hitung $=$ $0,597>\mathrm{r}$ tabel pada taraf signifikan $5 \%=0,176$, sehingga kesimpulan penelitian adalah adanya hubungan antara kecerdasan spiritual pada mahasiswa Fakultas Kedokteran Universitas Sebelas Maret.

Tahun 2013 sebuah penelitian berjudul "The Relationship between Spiritual Well-Being and Academic Achievement" penelitian dilakukan kepada 18.465 penduduk dengan jumlah sample 320 orang menggunakan stratified random sampling. Hasil penelitian menunjukkan ada hubungan yang signifikan dan positif antara tingkat kecerdasan spiritual dan prestasi akademik mahasiswa ekonomi, manajemen dan humaniora. Tapi, tidak ada hubungan yang signifikan antara kecerdasan spiritual dan prestasi akademik mahasiswa teknik dan ilmu-ilmu dasar dan seni dan arsitektur.(Abadi, Tabbodi, 2013)

\section{Landasaran teori}

Pengeluaran per mahasiswa

Pengeluaran per mahasiswa dibatasi pada dua biaya yaitu biaya konsumsi makanan dan bukan makanan (Dumairy, 1999). Seluruh biaya yang dikeluarkan oleh mahasiswa di peroleh dari uang saku yang diberikan oleh orangtua mahasiswa setiap bulannya. Latar belakang ekonomi keluarga mahasiswa berpengaruh dalam perilaku konsumsi mereka. Pada umumnya mahasiswa yang berasal dari keluarga kaya akan memiliki pengeluaran lebih banyak daripada mahasiswa yang berasal dari keluarga menengah ke bawah. Pengeluaran mahasiswa pada 4 Universitas terkemuka di Bangladesh menunjukkan bahwa pendapatan bulanan dari keluarga atau uang saku dalam fungsi linear menunjukkan bahwa ada hubungan positif antara pengeluaran konsumsi per mahasiswa dan prestasi akademik Mahasiswa (H. Akther, K. A. Lima (2015). Pengeluaran non rutin yang mendukung kegiatan akademis seperti pembelian buku, foto copy, pembelian alat peraga dan biaya mengikuti pelatihan memberi dampak pada prestasi mahasiswa.

\section{Motivasi belajar}

Motivasi belajar adalah elemen yang mendorong siswa mau belajar dan berproses untuk maju lebih baik. Hal senada didukung oleh Alderfer bahwa motivasi belajar adalah kecenderungan siswa dalam melakukan segala kegiatan belajar yang didorong oleh hasrat untuk mencapai prestasi atau hasil belajr sebaik mungkin (Clayton Alderfer, 1969). Di dukung oleh Winkel yang mendefenisikan motivasi belajar merupakan faktor psikis yang bersifat non-intelektual, peranannya yang khas adalah gairah atau semangat belajar, sehingga seorang siswa yang bermotivasi kuat, siswa mempunyai banyak energi untuk melakukan kegiatan belajar. Dengan demikian, siswa yang mempunyai motivasi kuat akan mempunyai semangat dan gairah belajar yang tinggi, dan pada gilirannya akan dapat mencapai prestasi belajar yang tinggi (Winkel, 1983:7).

\section{Kecerdasan Spiritual}

Kecerdasan Spiritual adalah cara kita menggunakan makna, nilai-nilai, tujuan, dan motivasi dalam proses berpikir dan pengambilan keputusan. (Zohar dan Marshall, 2001). Berbeda dengan pendapat ahli lain, Kecerdasan spiritual adalah kecerdasan yang digunakan untuk menyelesaikan dihadapi 
hidup permasalahan, orang diminta untuk mengubah penderitaan menjadi semangat kreatif (motivasi) hidup yang tinggi sehingga penderitaan berubah menjadi kegembiraan hidup. Manusia harus dapat menemukan makna hidup "(Abdul Wahid Hasan, 2006). Dalam berbagai penelitian menunjukkan adanya hubungan antara kecerdasan spiritual dengan indeks prestasi mahasiswa ekonomi dan manajemen (M.M. Abadi, M. Tabbodi. (2013).

\section{Prestasi Akademik}

Prestasi akademik mahasiswa yang kuliah dapat diukur dari nilai indeks prestasi yang diterima dari kampus. Setiap semester mahasiswa akan menerima laporan hasil study dalam bentuk nilai IPK (Indeks Prestasi Kumulatif) dengan bobot penilaian $0-4$ (nol sampai dengan empat). Menurut Winkel "prestasi belajar adalah suatu bukti keberhasilan belajar atau kemampuan seorang siswa/mahasiswa dalam melakukan kegiatan belajarnya sesuai dengan bobot yang dicapainya" (Winkel dikutip Sunarto, 1996).

\section{Model Analisis}

Model Analisis yang digunakan dalam penelitian ini adalah Ordinal Logistic Regression. Regresi logistic ordinal untuk menganalisis data dengan variabel respon merupakan skala ordinal yang terdiri dari tiga kategori atau lebih dan variabel prediktor merupakan covariate jika menggunakan skala interval atau rasio atau bisa merupakan faktor jika menggunakan skala nominal atau ordinal (Hosmer, 2000). Prestasi akademik mahasiswa dibagi menjadi 4 kategori yaitu sangat meningkat, meningkat, menurun dan sangat menurun.

Bentuk persamaan fungsional pertama sebagai berikut:

$$
\mathrm{Y} 1=\beta 0+\beta 1 \mathrm{X} 1+\mathrm{e} .
$$

$$
\begin{aligned}
& \mathrm{Y} 1=\text { prestasi akademik }(\text { satuan } \mathrm{IPK}) \\
& \mathrm{X} 1=\text { pengeluaran per mahasiswa }(\mathrm{Rp}) \\
& \mathrm{B} 0=\text { Konstanta } ; \mathrm{e}=\text { Error }
\end{aligned}
$$

Bentuk persamaan fungsional ke dua sebagai berikut:

$$
\mathrm{Y} 1=\beta 1+\beta 2 \mathrm{X} 2+\mathrm{e} .
$$

$\mathrm{Y} 1=$ prestasi akademik ( satuan IPK)

$\mathrm{X} 1=$ motivasi belajar

$\mathrm{B} 0=$ Konstanta; $\mathrm{e}=$ Error

Bentuk persamaan fungsional ke tiga sebagai berikut:

$$
\mathrm{Y} 1=\beta 1+\beta 2 \mathrm{X} 2+\mathrm{e}
$$

$$
\mathrm{Y} 1=\text { prestasi akademik (satuan IPK) }
$$

$\mathrm{X} 1$ = tingkat kecerdasan spiritual

$$
\mathrm{B} 0=\text { Konstanta } ; \mathrm{e}=\text { Error }
$$

\section{Hipotesis penelitian}

H1: Pengeluaran per mahasiswa berpengaruh terhadap prestasi akademik mahasiswa

H2 : Motivasi belajar mahasiswa berpengaruh terhadap prestasi akademik mahasiswa

H3: Kecerdasan spiritual berpengaruh terhadap prestasi akademik mahasiswa

\section{METODE PENELITIAN Analisis Statistik}


Penelitian ini menggunakan analisis statistik deskriptif. Analisis statistic deskriptif adalah statistik yang digunakan untuk menganalisis data dengan cara mendeskripsikan data yang telah terkumpul sebagaimana adanya tanpa bermaksud membuat kesimpulan yang berlaku untuk umum atau generalisasi. Analisis statistika penelitian ini diolah menggunakan program SPPS (Statistical program for social science). Program SPSS adalah program computer statistic yang dapat mengolah data statistic dengan tepat dan akurat menjadi hasil output yang diharapkan para peneliti. Tujuan analisis statistic data untuk menguji hipotesis yang disusun peneliti dan membuat kesimpulan akhir penelitian (Arikunto, 2006).

\section{Populasi dan Sampel}

Populasi dalam penelitian ini yaitu mahasiswa manajemen Universitas Ciputra Surabaya. Tercatat ada 1.308 mahasiswa yang aktif pada saat penelitian. Metode pemilihan sample menggunakan sampling purposive. Sampling purposive adalah teknik penentuan sampel dengan pertimbangan tertentu (Sugiono, 2001). Pemilihan sekelompok subjek dalam purposive sampling didasarkan atas ciri-ciri tertentu yang dipandang mempunyai sangkut paut yang erat dengan ciriciri populasi yang sudah diketahui sebelumnya, dengan kata lain unit sampel yang dihubungi disesuaikan dengan kriteria-kriteria tertentu yang diterapkan berdasarkan tujuan penelitian (Margono, 2004). Sample di penelitian ini adalah mahasiswa IBM yang telah mengikuti tahun ajaran 2015/2016 dan sudah mendapatkan IPK untuk tahun ajaran tersebut. Karena jumlah Mahasiswa IBM sebanyak 1.308, maka sampel yang di ambil menggunakan perhitungan rumus Slovin dengan tingkat kesalahan 10 persen dengan rincian sebagai berikut:

$$
\mathrm{N}=\frac{N}{1+N(e) 2}=\frac{1308}{1+1308(0,1) 2}=92
$$

Sesuai dengan rumus diatas, maka jumlah sample mahasiswa yang mengisi angket di penelitian ini adalah 92 mahasiswa. Selama pengumpulan data ditemukan ada 6 mahasiswa yang tidak mengisi dengan lengkap dan 86 mahasiswa yang mengisi secara tepat dan lengkap.

\section{Defenisi Operasional Variabel}

Variable dalam penelitian ini meliputi 4 variabel antara lain 3 variabel bebas dan 1 variabel terikat. Varibel terikat (Y) yaitu Prestasi akademik mahasiswa. Prestasi mahasiswa diukur dari hasil IPK mahasiswa secara bersamaan pada tahun 2015/2016. Adapun defenisi operasional masing masing variable yaitu

1. Variable terikat (Y) yaitu prestasi akademik menggunakan Indeks Prestasi (IP) tahun ajaran 2015/2016.

2. Variabel bebas (X1) yaitu pengeluaran per mahasiswa dengan satuan Rupiah.

3. Variabel bebas (X2) yaitu motivasi belajar dibagi 4 kategori.

4. Variabel bebas (X3) yaitu tingkat kecerdasan spiritual dibagi 4 kategori.

\section{Pengolahan data}

Data variabel motivasi belajar di bagi dalam 4 kategori sebelum data diolah menggunakan program SPPS. Kategori ini didasarkan pada penghitungan skala linkert dan jumlah butir soal ada 15 soal. Penskoran $=1-5$ dengan skala Linkert, seperti di bawah ini.

\section{Tabel 1. Kategori motivasi belajar}

\begin{tabular}{lll}
\hline Skala Linkert & Interval & Motivasi belajar \\
\hline Skor terendah ideal $=15 \times 1=15$ & $15-30$ & $1=$ Sangat rendah \\
Skor rendah ideal $=15 \times 2=30$ & $31-45$ & 2= Rendah \\
Skor tengah ideal $=15 \times 3=45$ & $46-60$ & $3=$ Tinggi \\
Skor tinggi ideal $=15 \times 4=60$ & $61-75$ & $4=$ Tinggi \\
Skor tertinggi ideal $=15 \times 5=75$ & & \\
\end{tabular}


Data variabel kecerdasan spiritual dalam penelitian ini diukur dengan menggunakan skala kecerdasan spiritual yang disusun sendiri oleh peneliti berdasarkan kategori dan indikator kecerdasan spiritual. Kategori ini didasarkan pada penghitungan skala linkert dan jumlah butir soal ada 15 soal. Penskoran $=1-5$ dengan skala Linkert, seperti di bawah ini.

\section{Tabel 2. Kategori kecerdasan spiritual}

\begin{tabular}{lll}
\hline Skala Linkert & Interval & Motivasi belajar \\
\hline Skor terendah ideal $=10 \times 1=10$ & $10-20$ & $1=$ Sangat rendah \\
\cline { 2 - 3 } Skor rendah ideal $=10 \times 2=20$ & $21-30$ & $2=$ Rendah \\
\cline { 2 - 3 } Skor tengah ideal $=10 \times 3=30$ & $31-40$ & $3=$ Tinggi \\
Skor tinggi ideal $=10 \times 4=40$ & $41-50$ & $4=$ Sangat tinggi \\
Skor tertinggi ideal $=10 \times 5=50$ & & \\
\hline
\end{tabular}

Data variabel Prestasi akademik dibagi dalam 4 kategori. Kategori ini di dasarkan pada penghitungan indeks prestasi skala $1-4$. Sumber Data primer yang diperoleh dari mahasiswa yang baru menerima hasil IP tahun ajaran 2015/2016.

Tabel 3: Kategori Prestasi akademik

\begin{tabular}{lll}
\hline No & Interval & Tingkat prestasi akademik \\
\hline 1 & Dibawah $-0,25$ & $1=$ Sangat menurun \\
\hline 2 & Antara $-0,25 \mathrm{~s} / \mathrm{d} 0$ & $2=$ Menurun \\
\hline 3 & Antara $0 \mathrm{~s} / \mathrm{d} 0,25$ & $3=$ Meningkat \\
\hline 4 & Diatas 0,25 & $4=$ Sangat meningkat \\
\hline
\end{tabular}

\section{Kerangka Konseptual Penelitian}

Kerangka konseptual dalam penelitian ini berdasarkan landasan teori dan penelitian terdahulu sebagai berikut :

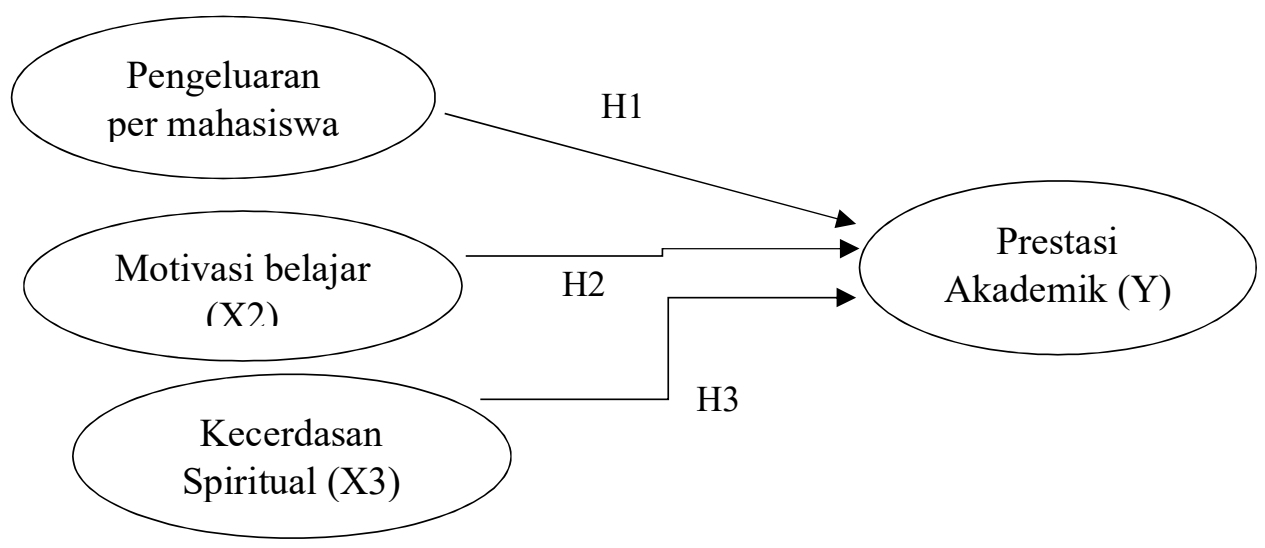

\section{HASIL DAN PEMBAHASAN Analisis Dekriptif}

Untuk memperoleh gambaran masing masing variable penelitian, maka berikut ini dipaparkan statistic deskriptif pada tabel di bawah ini. 
Tabel 4. Statistik deskriptif

\begin{tabular}{llrr}
\hline & & N & Marginal Percentage \\
\hline Prestasi akademik & sangat menurun & 5 & $5.8 \%$ \\
\cline { 2 - 4 } & Menurun & 19 & $22.1 \%$ \\
\cline { 2 - 4 } & Meningkat & 27 & $31.4 \%$ \\
\cline { 2 - 4 } Motivasi belajar & sangat meningkat & 35 & $40.7 \%$ \\
\cline { 2 - 4 } & sangat rendah & 5 & $5.8 \%$ \\
\cline { 2 - 4 } & Rendah & 30 & $34.9 \%$ \\
\cline { 2 - 4 } & tinggi & 51 & $59.3 \%$ \\
\hline Spiritualitas & tinggi & 37 & $43.0 \%$ \\
\cline { 2 - 4 } & sangat tinggi & 49 & $57.0 \%$ \\
\hline Valid & & 86 & $100.0 \%$ \\
\hline Missing & & 86 & \\
\hline Total & & 017 & \\
\hline
\end{tabular}

Sumber: data diolah, 2017

Dari hasil statistik deskriptif diatas menunjukkan bahwa seluruh jumlah responden mahasiswa IBM 86 orang. Mahasiswa dengan IP sangat rendah ada 5 mahasiswa, IP menurun ada 19 mahasiswa, IP meningkat ada 27 mahasiswa dan IP sangat meningkat ada 35 mahasiswa. Jumlah mahasiswa dengan tingkat motivasi yang sangat rendah ada 5 mahasiswa, rendah ada 30 mahasiswa dan tinggi 51 mahasiswa. Sedangkan kecerdasan spiritual mahasiswa kategori tinggi ada 37 mahasiswa dan sangat tinggi ada 49 mahasiswa

\section{Hasil Uji Statistik}

Hasil uji statistik untuk mengetahui model hubungan antara Pengeluaran per mahasiswa, Motivasi belajar dan Kecerdasan spiritual dengan prestasi akademik di jelaskan pada hasil output yang dianalisis pada 86 mahasiswa manajemen sebagai berikut:

Tabel 5. Model Fitting Information

\begin{tabular}{lrrrr}
\hline Model & -2 Log Likelihood & Chi-Square & df & Sig. \\
\hline Intercept Only & 158.008 & & & \\
\hline Final & 155.126 & 2.883 & 4 & .578 \\
\hline Sulm
\end{tabular}

Sumber : data diolah, 2017

Berdasarkan model fitting information di tabel 5, diketahui bahwa p-value nya 0,578 (p-value $>$ $0,05)$, dimana output ini didasarkan pada hipotesis berikut ini :

Ho: model yang hanya mengandung intersep cocok digunakan

H1: model yang hanya mengandung intersep tidak cocok digunakan.

$\alpha=0,05$; Statistik uji Chi square

$x^{2}$ dengan derajat bebas 2

$\mathrm{p}$-value $=0,578>0,05$

Kesimpulannya ialah model yang hanya mengandung intersep cocok digunakan. Dengan kata lain, model persamaan yang cocok digunakan adalah model yang tidak mengandung variabel bebasnya. 
Tabel 6. Goodness-of-Fit

\begin{tabular}{lrrr}
\hline & Chi-Square & df & \multicolumn{1}{l}{ Sig. } \\
\hline Pearson & 129.553 & 137 & .662 \\
\hline Deviance & 121.784 & 137 & .820 \\
\hline
\end{tabular}

Sumber : data diolah, 2017

Uji goodness of fit, didapatkan nilai Chi-square untuk Pearson adalah 129.553 dengan p-value 0.662 dan Deviance sebesar 121.789 dengan p-value 0.820. Deviance menunjukkan ukuran seberapa banyak variasi yang tidak dapat dijelaskan oleh model regresi logistik. Semakin tinggi nilai deviance semakin kurang akurat modelnya. Adapun bentuk hipotesis untuk pengujian goddness of fit ini adalah sebagai berikut :

Ho : data sesuai dengan prediksi model regresi logistik

$\mathrm{H}_{1}$ : data tidak sesuai dengan prediksi model regresi logistik

$\alpha=0,05$

Statistik uji Chi Square untuk Pearson $x^{2}$ dengan derajat bebas 85 .

$\mathrm{p}$-value $=0,662>0,05 ;$ Keputusan : terima Ho

Kesimpulan adalah data yang dihasilkan dari observasi sesuai dengan prediksi model regresi logistik ordinal yang digunakan dan berarti bahwa model ini yang digunakan.

\begin{tabular}{cc}
\multicolumn{2}{c}{ Tabel 7 : Pseudo R-Square } \\
\hline Cox and Snell & .033 \\
\hline Nagelkerke & .036 \\
\hline McFadden & .014 \\
\hline Sur
\end{tabular}

Sumber : data diolah, 2017

Berdasarkan hasil dari Pseudo R-square didapatkan nilai Nagelkerke sebesar $3.6 \%$. Hal ini mengindikasikan bahwa variabel Pengeluaran per mahasiswa, motivasi belajar dan kecerdasan spiritual mampu menjelaskan variasi indeks prestasi mahasiswa hanya sebesar 3.6\%, sisanya dipengaruhi oleh variabel lainnya.

Tabel 8. Parameter Estimates

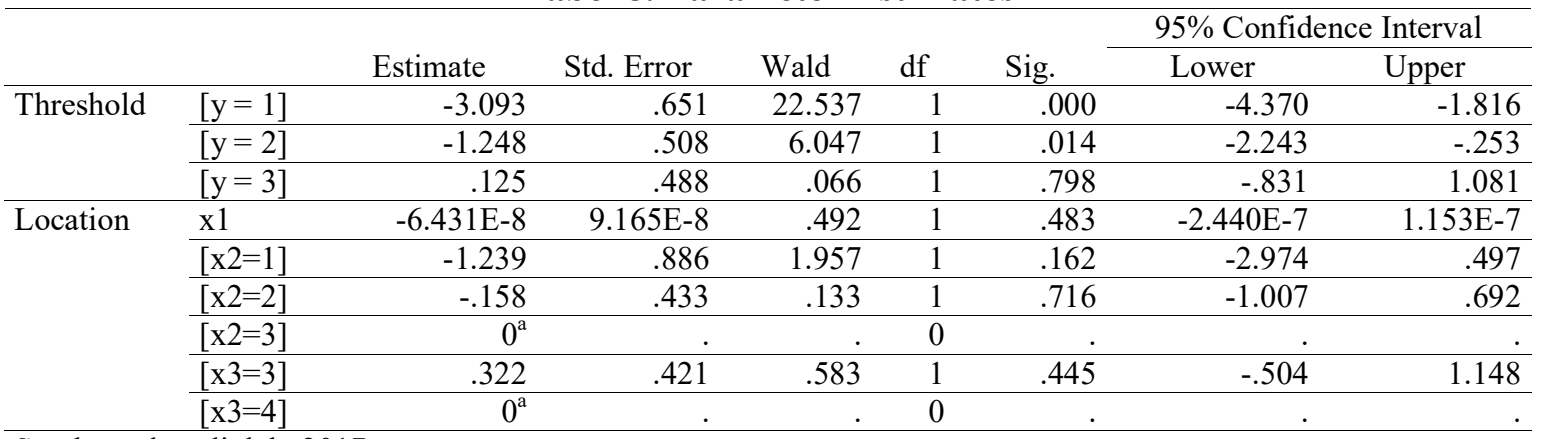

Sumber : data diolah, 2017

Dari tabel diatas diperoleh hasil bahwa indeks prestasi mahasiswa sangat menurun $(\mathrm{Y}=1)$ dan menurun $(\mathrm{Y}=2)$ bukan di pengaruhi oleh ke 3 variabel bebas yaitu $\mathrm{X} 1=$ pengeluaran per mahasiswa, X2 = motivasi belajar dan X3 = kecerdasan mahasiswa. Karena hanya 3,6 \% ke -3 variabel ini memberi efek kepada indeks prestasi mahasiswa. 


\section{Pengaruh kecerdasan spiritual terhadap prestasi akademik mahasiswa}

Hasil penelitian ini menunjukkan bahwa menurunnya indeks prestasi mahasiswa bukan dipengaruhi oleh peningkatan kecerdasan spiritual. Justru kemampuan mahasiswa dalam mengatasi permasalahan hidup dan menyelesaikan tugas kuliah dengan baik mendorong meningkatnya indeks prestasi mahasiswa. Oleh karena itu, mahasiswa harus mampu menyaring pergaulan sesama teman, hindari pergaulan yang buruk di kampus.

\section{KESIMPULAN}

Ada sebanyak 5 mahasiswa masuk dalam kategori indeks prestasi (IP) sangat menurun. Dan sebanyak 19 mahasiswa masuk dalam kategori indeks prestasi (IP) menurun. Namun turunnya indeks prestasi mahasiswa tersebut bukan karena efek dari pengeluaran per mahasiswa, tingkat motivasi belajar dan kecerdasan spiritual. Tapi dipengaruhi oleh factor lain yang belum diketahui sebesar 96\%. Oleh karena itu, para dosen dan orangtua mahasiswa harus tetap memberikan dukungan materi, motivasi dan dukungan spiritual kepada mahasiswa untuk menghindari indeks prestasi buruk.

\section{REFERENSI}

Arikunto S. (2006). Prosedur Penelitian Suatu Pendekatan Praktik. Edisi Revisi 6, Penerbit PT Rineka Cipta, Jakarta.

Clinton. (2015). Survei Biaya Hidup Mahasiswa Berdasarkan Pengeluaran Konsumsi Makanan dan Non Makanan (Study kasus Mahasiswa Fakultas MIPA), IPB, Bogor.

Dumairi. (1999). Perekonomian Indonesia. Erlangga, Yogyakarta.

Effendi, A. (2005). Revolusi Kecerdasan Abad 21. Aflabeta, Bandung.

H. Akther, K. A. Lima. (2015). Consumption Expenditure and Students' Academic Performance. An Econometric Analysis Of PublicUniversity Students in Bangladesh, International

Journal of Multidisciplinary Academic Research Vol. 3, No. 1.

Hasan, A.W. (2006). Aplikasi Strategi Dan Model Kecerdasan Spiritual (SQ) Rasulullulah di Masa Kini. Yogyakarta.

Hosmer, D.W., Lemeshow, S. (2000). Applied Logistic Regression, Second Edition. NewYork: Wiley and Sons.

M.M. Abadi, M. Tabbodi. (2013). The Relationship between Spiritual Well-Being and Academic Achievement. European Online Journal of Natural and Social Sciences, No.3, Special Issue on Accounting and Management, 2013.

Michelle B, Bud Meyers, and John D. (2014). Spending and Student Achievement: Money Matters When Equity is at Issue. A Publication of The University Of Vermont James M. Jeffords Center, Issue Brief Vol 4, No 1 January 2014.

Samuelson, Paul A., William D. Nordhaus. (1996). Makro Ekonomi, Edisi Keempatbelas, Cetakan Ketiga, Erlangga, Jakarta.

Sugiono. (2008). Metode Penelitian Kuantitatif, Kualitatif dan R\&D. Penerbit Alfabeta,Bandung. William, E, \& Larry, M, (2012). The Relationship Between per Pupil Expenditures and Student

Achievement in Tennessee. American Inetrnational Journal of Contemporary Research, Vol 2, No. 3, March 2012.

WS. Winkel. (1983). Psikologi Pendidikan dan Evaluasi Belajar. Gramedia, Jakarta. 